\title{
PENGARUH KADAR AIR DAN JARAK ANTAR PAKU TERHADAP KEKUATAN SAMBUNGAN KAYU KELAPA
}

\author{
Arusmalem Ginting ${ }^{[1]}$
}

\begin{abstract}
ABSTRAK
Kayu kelapa sebagai kayu alternatif sudah banyak digunakan sebagai bahan bangunan. Bangunan dapat berupa bangunan terlindung dan bangunan tidak terlindung. Kadar air kayu dipengaruhi oleh kelembaban udara sekitarnya yang sering disebut sebagai sifat higroskopis kayu. Kayu kelapa yang ada di pasaran juga mempunyai kadar air yang berbeda-beda. Sambungan merupakan titik terlemah pada struktur kayu. Kekuatan sambungan dipengaruhi oleh beberapa faktor diantaranya kadar air dan jarak alat sambung. Tujuan dari penelitian ini adalah untuk mengetahui berat jenis kayu kelapa, pengaruh kadar air, dan jarak antar paku terhadap kekuatan sambungan. Pada penelitian ini digunakan 3 variasi kadar air yaitu 8,27 \%, 16,28 \% dan 33,44 \%. Jarak antar paku yang digunakan adalah 8D, 10D dan 12D, dengan D adalah diameter paku. Digunakan 10 buah paku 4'BWG8 dengan diameter 0,42 cm dan panjang 10,2 cm yang ditempatkan dalam 2 baris. Sambungan kayu kelapa yang diuji menggunakan pelat sambung kayu, tebal batang utama $4 \mathrm{~cm}$, lebar $8 \mathrm{~cm}$ dan pelat sambung ganda tebal $2 \mathrm{~cm}$, lebar $8 \mathrm{~cm}$. Dari hasil penelitian didapat berat jenis kayu kelapa 0,74. Jarak paku yang kurang dari jarak minimum (10D) mengurangi kekuatan sambungan dan jarak paku yang lebih dari jarak minimum (10D) akan meningkatkan kekuatan sambungan. Kekuatan sambungan meningkat pada kadar air kurang dari kondisi kering udara (16,28 \%) dan menurun pada kadar air melebihi kondisi kering udara (16,28 \%). Besarnya faktor aman sambungan kayu kelapa menggunakan alat sambung paku (4'’BWG8) pada kondisi kering udara (16,28 \%) dan jarak paku minimum (10D) sebesar 2,86.
\end{abstract}

Kata kunci : Kadar air, Jarak paku, Kekuatan sambungan, Kayu kelapa.

\begin{abstract}
Coconut wood has often been used as alternative wood for the building materials. The structure condition could be protected or unprotected from the change atmosphere humidity. Moisture content of wood was affected by humidity of surrounding atmosphere that was acknowledged as the hygroscopic characteristics. Coconut wood in commercial had the moisture content that was different. Connection was the weakest point in wood structures. The strength of connection was influenced by several factors like the moisture content and spacing of fastener. The goal of this research was to know the specific gravity of coconut wood, influence of moisture content and spacing of nail towards the strength of connection. In this research was used 3 variations of moisture content that was $8.27 \%$, $16.28 \%$ and $33.44 \%$. The spacing variation of the nail was 8D, 10D and 12D, with D was the diameter of the nail. Used 10 nail 4',BWG8 with the diameter 0,42 cm and long 10,2 cm that was placed in 2 rows. Connection of coconut wood that was tested used wood side plates, thickly the main member $4 \mathrm{~cm}$, wide $8 \mathrm{~cm}$ and wood side plates thick $2 \mathrm{~cm}$, wide $8 \mathrm{~cm}$. Results of the research was gotten the specific gravity coconut wood 0.74. Nail spacing less than minimal spacing (10D) reduced the strength of connection and the spacing that larger than minimal spacing (10D) increased the strength of connection. The strength of connection increased on moisture content less than air-dry condition (16,28 \%) and descended on moisture content exceeded air-dry condition (16,28 \%). The safe factor connection of coconut wood used the nail fastening (4', BWG8) in air-dry condition (16,28 $\%)$ and minimal spacing (10D) was 2.86.
\end{abstract}

Keywords : Moisture content, Nail spacing, Strength of connection, Coconut wood. 


\section{PENDAHULUAN}

Penebangan hutan secara liar yang tidak terkendali selama puluhan tahun menyebabkan terjadinya penyusutan hutan tropis secara besar-besaran yang mengakibatkan kurangnya pasokan kayu dan semakin tingginya harga kayu di pasaran. Untuk mengatasi hal tersebut maka perlu dicari alternatif pengganti kayu.

Indonesia merupakan salah satu negara yang memiliki areal perkebunan kelapa yang cukup luas. Hampir semua kawasan pantai Indonesia terdapat tanaman kelapa. Pemanfaatan kayu kelapa dilakukan sebagai alternatif pengganti kayu. Berdasarkan penelitian-penelitian yang sudah dilakukan, kayu kelapa cukup kuat digunakan sebagai bahan bangunan.

Kayu merupakan bahan bangunan yang bersifat higroskopis, yaitu bahan bangunan yang sangat peka terhadap perubahan udara yang mengakibatkan perubahan kadar air. Penggunaan kayu sebagai bahan bangunan dapat digunakan pada struktur terlindung, tidak terlindung dan struktur yang terendam air. Struktur terlindung yaitu struktur yang terlindung dari perubahan udara yang besar, dari hujan dan matahari, sehingga tidak basah dan kadar airnya tidak akan berubah-ubah banyak. Struktur tidak terlindung adalah struktur yang tidak dilindungi dari perubahan udara yang besar tetapi kayu dapat mengering dengan cepat. Struktur yang terendam dalam air adalah struktur untuk bangunan-bangunan di sungai dengan kadar air yang selalu tinggi.

Sambungan merupakan titik terlemah pada struktur kayu. Sambungan pada struktur kayu dapat berupa sambungan paku, baut, pasak, perekat atau dapat juga menggunakan alat sambung modern (modern timber connector). Sambungan paku sering digunakan pada kayu lunak atau kayu dengan berat jenis rendah. Faktor-faktor yang mempengaruhi kekuatan sambungan diantaranya adalah jarak alat sambung dan kadar air kayu. Pada peraturanperaturan (code) biasanya dicantumkan faktor reduksi kekuatan sambungan sesuai dengan kondisi lingkungan struktur dan juga dicantumkan jarak minimum antar alat sambung. Kayu kelapa sebagai kayu alternatif perlu diketahui perilaku sambungannya.

Tujuan dari penelitian ini adalah untuk mengetahui pengaruh kadar air dan jarak antar paku terhadap kekuatan sambungan kayu kelapa.

\section{TINJAUAN PUSTAKA}

\subsection{Kayu Kelapa}

Kayu kelapa (Cocos Nucifera L) atau pohon nyiur merupakan salah satu pohon di daerah tropis yang termasuk keluarga palmaceae dan golongan monocotyledoneae. Pohon ini 
tumbuh di daerah pantai, tinggi pohon kelapa berkisar antara 15 - 40 m dengan diameter batang 0,25 - 0,40 m. Pertumbuhan batang lurus ke atas dan tidak bercabang. Pada ujung batang terdapat titik tumbuh yang merupakan jaringan meristem yang berfungsi untuk membentuk daun, bunga dan batang. Pada usia 3 - 4 tahun lingkaran pada batang tidak membesar lagi. Hal ini disebabkan pada pohon kelapa tidak mempunyai kambium, sehingga tidak dapat mengalami pertumbuhan sekunder. Pertumbuhan pohon kelapa setiap tahun bertambah tinggi sebesar 1 - 1,5 m untuk tanaman muda, 0,4-0,5 m untuk tanaman dewasa dan 0,1 m untuk tanaman yang sudah tua (Setyamidjaja, 1995).

\subsection{Kadar Air}

Kadar air kayu adalah banyaknya air yang ada didalam sepotong kayu dinyatakan sebagai porsentase dari berat kayu kering oven. Banyaknya kandungan air pada kayu bervariasi tergantung dari suhu dan kelembaban udara disekitarnya dan tergantung dari jenis kayu. Semua sifat fisik kayu sangat dipengaruhi oleh perubahan kadar air kayu. Oleh karena itu dalam penggunaan kayu sebagai bahan baku bangunan perlu diketahui kandungan kadar airnya (Dumanauw, 1984).

Menurut Kasmujo (2001) kadar air besarnya bervariasi menurut jenis kayu, dan perbedaan umur kayu. Kayu dari mulai ditebang sampai siap dibuat produk akan mengalami penurunan kadar air. Kadar air kering udara di Indonesia berkisar antara 10-18\%. Pada jenisjenis kayu dengan berat jenis rendah, kadar air 18\% sudah mencapai kondisi kering udara. Di daerah iklim tropis kadar air seimbang didalam ruangan kurang dari 10\%, sedang di luar ruangan lebih dari 20\%. Dalam ruang ber-AC kadar air seimbang kurang dari 10\% demikian juga ruangan yang dilengkapi dengan pemanas. Kayu dalam kondisi kering udara jika terus dikeringkan, maka kadar airnya masih bisa berkurang lagi hingga tinggal 0 - 1\% saja. Kadar air pada kondisi teoritis $0 \%$ disebut kondisi kering tanur dan relatif labil artinya mudah berubah.

Berdasarkan PKKI (1961) kadar air kayu dapat dibagi menjadi 3 golongan yaitu kadar air basah, kadar air kering udara, dan kadar air kering mutlak. Kayu yang baru ditebang dan masih basah kadar airnya antara 40 - $200 \%$, dan besarnya kadar air ini juga tergantung jenis kayu. Kayu basah makin lama makin kering hingga mencapai kadar air antara 24 - 30 \% yang dinamakan fiber saturation point. Kadar air dibawah fiber saturation point akan mengakibatkan penyusutan dan meningkatkan kekuatan kayu, sedangkan kadar air di atas fiber saturation point mengakibatkan penurunan kekuatan kayu. Kadar air kayu kering udara di Indonesia antara 12 - $18 \%$ atau rata-rata $15 \%$. 


\subsection{Berat jenis}

Berat jenis kayu adalah perbandingan berat kayu terhadap volume air yang sama dengan volume kayu tersebut dengan menggunakan berat kayu kering sebagai dasar. Faktor tempat tumbuh dan iklim, letak geografis dan spesies dapat berpengaruh terhadap berat jenis, demikian pula letak bagian kayunya berpengaruh terhadap berat jenis kayu (Haygreen dan Bowyer, 1996).

Setiap jenis kayu mempunyai berat jenis yang berbeda, berkisar antara minimum 0,2 (kayu balsa) hingga 1,28 (kayu nani). Berat jenis merupakan petunjuk penting bagi aneka sifat kayu. Makin besar berat jenis kayu, umumnya makin kuat pula kayunya dan semakin kecil berat jenis kayu, akan berkurang pula kekuatanya (Dumanauw, 1984).

Menurut Haygreen dan Bowyer (1996), kemungkinan kondisi kayu yang dipakai untuk menyatakan berat jenis adalah:

a. Volume basah, yaitu volume dimana dinding sel sama sekali basah atau jenuh dengan air atau berada pada kondisi titik jenuh serat atau diatasnya.

b. Volume pada keadaan seimbang, yaitu kayu pada kondisi kadar air dibawah titik jenuh serat.

c. Volume kering tanur, yaitu kondisi berat konstan setelah dikeringkan dalam tanur pada suhu $\pm 103^{\circ} \mathrm{C}$.

Berdasarkan penelitian yang dilakukan oleh Sektianto (2001) berat jenis rata-rata kayu kelapa sebesar 0,54.

Isyuanto (2002) meneliti lapis luar dan lapis dalam kayu kelapa. Dari hasil penelitian didapat berat jenis rata-rata lapis luar kayu kelapa 0,725 dan berat jenis rata-rata lapis dalam kayu kelapa 0,721. Perbedaan berat jenis lapis luar dan lapis dalam tidak terlalu besar dan kayu kelapa digolongkan sebagai kayu kelas kuat II.

Berdasarkan PKKI 1961 hubungan antara berat jenis dan kelas kuat kayu adalah seperti pada Tabel 1 .

Tabel 1. Hubungan antara berat jenis dan kelas kuat kayu (PKKI 1961)

\begin{tabular}{|c|c|c|c|}
\hline $\begin{array}{c}\text { Kelas kuat } \\
\text { kayu }\end{array}$ & Berat jenis & $\begin{array}{c}\text { Kuat lentur mutlak } \\
\mathrm{kg} / \mathrm{cm}^{2}\end{array}$ & $\begin{array}{c}\text { kuat tekan mutlak } \\
\mathrm{kg} / \mathrm{cm}^{2}\end{array}$ \\
\hline I & $>0,90$ & $>1100$ & $>650$ \\
\hline II & $0,90-0,60$ & $1100-725$ & $650-425$ \\
\hline III & $0,60-0,40$ & $725-500$ & $425-300$ \\
\hline IV & $0,40-0,30$ & $500-360$ & $300-215$ \\
\hline V & $<0,30$ & $<360$ & $<215$ \\
\hline
\end{tabular}




\subsection{Sambungan Paku}

Menurut Soehendrodjati (1990) pemakaian paku sebagai alat sambung banyak digunakan, baik untuk alat sambung perabot rumah tangga, kusen, pintu, jendela maupun sambungan struktur bangunan. Beberapa keuntungan penggunaan paku adalah sebagai berikut :

a. Paku merupakan alat sambung yang murah, sehingga harga struktur menjadi murah.

b. Sambungan paku bersifat kaku, sesaran kecil, sehingga struktur menjadi lebih kokoh.

c. Pelaksanaan pekerjaan cepat, mudah, tidak memerlukan tenaga ahli, peralatanya cukup dengan palu dan catut saja.

d. Perlemahan pada tampang kecil.

e. Penyimpangan arah gaya terhadap arah serat tidak mempengaruhi kekuatan dukung.

Berdasarkan PKKI (1961) syarat-syarat dan cara perhitungan sambungan paku adalah sebagai berikut :

a. Paku yang digunakan dapat mempunyai tampang melintang yang berbentuk bulat, persegi atau beralur lurus.

b. Kekuatan paku tidak tergantung dari besar sudut antara gaya dan arah serat kayu.

c. Ujung paku yang keluar dari sambungan sebaiknya dibengkokkan tegak lurus arah serat, asal pembengkokkan tersebut tidak akan merusak kayu.

d. Apabila dalam satu baris lebih dari 10 batang paku maka kekuatan paku harus dikurangi dengan 10\%, dan jika lebih dari 20 batang harus dikurangi 20\%.

e. Pada sebuah sambungan paku, paling sedikit harus digunakan 4 batang paku.

Jarak paku minimum diatur sebagai berikut:

a. Jarak paku searah gaya dengan tepi kayu yang dibebani sebesar 12d, untuk tepi kayu yang tidak dibebani sebesar $5 \mathrm{~d}$, dan jarak antar paku 10d, dengan $\mathrm{d}$ adalah diameter paku.

b. Jarak paku arah tegak lurus gaya ke tepi kayu 5d dan jarak antar baris 5d.

Kekuatan sambungan paku tampang dua ( $\mathrm{b} \leq 7 . \mathrm{d})$ dapat dihitung dengan Persamaan 1 berikut ini :

$$
\mathrm{S}=\text { b. d. } \sigma_{\mathrm{kd}}
$$

dengan: $\mathrm{S} \quad$ = gaya dukung satu paku, $(\mathrm{kg})$

b = tebal kayu tepi, $(\mathrm{cm})$

$\mathrm{d} \quad=$ diameter paku, $(\mathrm{cm})$

$\sigma_{\mathrm{kd}} \quad=$ kuat desak kayu, $\left(\mathrm{kg} / \mathrm{cm}^{2}\right)$ 


\section{CARA PENELITIAN}

Benda uji yang digunakan pada penelitian ini adalah kayu 4/8 cm yang disambung dengan pelat sambung $2 \times 2 / 8 \mathrm{~cm}$ menggunakan 10 buah paku 4"BWG8 dengan panjang 10,2 cm dan diameter (D) 0,42 cm. Untuk lebih jelasnya dapat dilihat pada Gambar 1 .

Kadar air benda uji terdiri dari 3 variasi yaitu 8,27 \%, 16,28 \%, dan 33,44 \%. Jumlah benda uji yang diteliti sebanyak 27 buah dengan variasi seperti ditunjukkan pada Tabel 2.

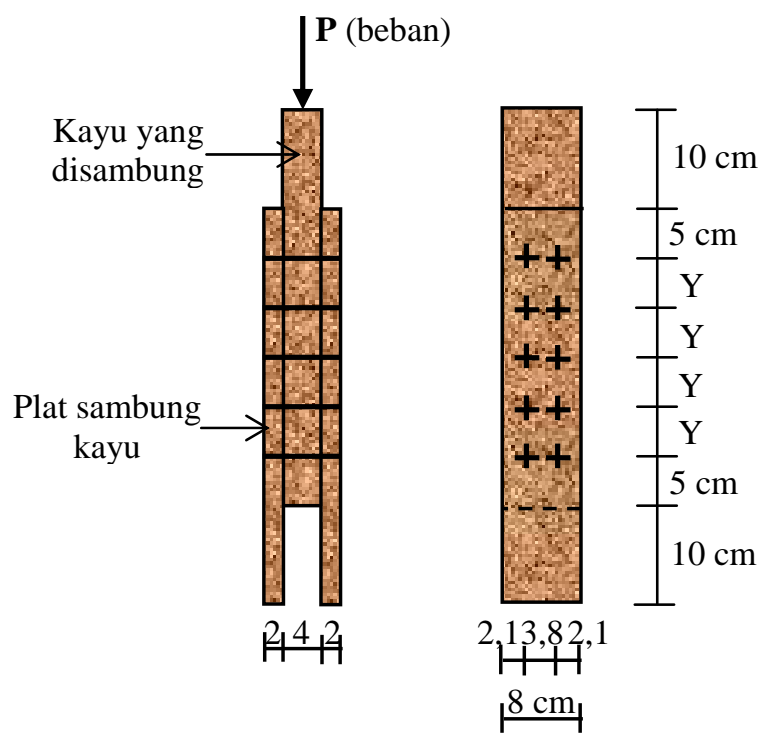

Gambar 1. Benda uji

Tabel 2. Variasi benda uji

\begin{tabular}{|c|c|c|c|c|}
\hline Variasi & Kadar air (\%) & Jarak paku & $\mathrm{Y}(\mathrm{cm})$ & Jumlah benda uji \\
\hline \multirow{3}{*}{ I } & \multirow{3}{*}{8,27} & $8 \mathrm{D}$ & 3,36 & 3 \\
\hline & & 10D & 4,20 & 3 \\
\hline & & 12D & 5,04 & 3 \\
\hline \multirow{3}{*}{ II } & \multirow{3}{*}{16,28} & $8 \mathrm{D}$ & 3,36 & 3 \\
\hline & & $10 \mathrm{D}$ & 4,20 & 3 \\
\hline & & 12D & 5,04 & 3 \\
\hline \multirow{3}{*}{ III } & \multirow{3}{*}{33,44} & $8 \mathrm{D}$ & 3,36 & 3 \\
\hline & & 10D & 4,20 & 3 \\
\hline & & $12 \mathrm{D}$ & 5,04 & 3 \\
\hline
\end{tabular}

Langkah-langkah yang dilakukan dalam penelitian ini adalah sebagai berikut :

1. Persiapan bahan meliputi pengadaan dan pengamatan visual kayu kelapa mengenai panjang dan cacat kayu.

2. Pemotongan kayu sesuai dimensi benda uji. 
3. Pembuatan dan proses pemakuan benda uji.

4. Pengujian desak benda uji menggunakan Universal Testing Machine (UTM).

5. Pengujian kadar air kayu yang diambil dari benda uji.

\section{HASIL DAN PEMBAHASAN}

\subsection{Kadar Air}

Hasil pemeriksaaan kadar air seperti pada Tabel 3, 4, dan 5. Dari Tabel 3 didapat besarnya kadar air benda uji variasi I sebesar 8,27 \%, kadar air ini sudah mencapai kadar air seimbang didalam ruangan yang besarnya kurang dari 10\%. Dari $\quad$ Tabel 4 didapat besarnya kadar air benda uji variasi II sebesar 16,28 \%, kadar air ini sudah mencapai kering udara karena kadar air kering udara di Indonesia berkisar antara 10-18\%. Dari Tabel 5 didapat besarnya kadar air benda uji variasi III sebesar 33,44 \%, kadar air ini di atas fiber saturation point yang mengakibatkan penurunan kekuatan kayu.

Tabel 3. Kadar air variasi I

\begin{tabular}{|c|c|c|c|}
\hline Benda uji & $\begin{array}{c}\text { Berat awal } \\
\text { (gr) }\end{array}$ & $\begin{array}{c}\text { Berat kering oven } \\
\text { (gr) }\end{array}$ & Kadar air (\%) \\
\hline 1 & 7,70 & 7,09 & 8,60 \\
\hline 2 & 6,97 & 6,41 & 8,74 \\
\hline 3 & 8,85 & 8,14 & 8,72 \\
\hline 4 & 4,70 & 4,43 & 6,09 \\
\hline 5 & 4,80 & 4,35 & 10,34 \\
\hline 6 & 6,86 & 6,33 & 8,37 \\
\hline 7 & 4,72 & 4,24 & 11,32 \\
\hline 8 & 6,75 & 6,25 & 8,00 \\
\hline 9 & 9,80 & 9,40 & 4,26 \\
\hline \multicolumn{4}{|r}{ Kadar air rata-rata } \\
\hline
\end{tabular}

Tabel 4. Kadar air variasi II

\begin{tabular}{|c|c|c|c|}
\hline Benda uji & $\begin{array}{c}\text { Berat awal } \\
\text { (gr) }\end{array}$ & $\begin{array}{c}\text { Berat kering oven } \\
\text { (gr) }\end{array}$ & Kadar air (\%) \\
\hline 1 & 3,55 & 3,02 & 17,55 \\
\hline 2 & 6,06 & 5,10 & 18,82 \\
\hline 3 & 5,08 & 4,30 & 18,14 \\
\hline 4 & 8,33 & 7,20 & 15,69 \\
\hline 5 & 7,35 & 6,45 & 13,95 \\
\hline 6 & 7,63 & 6,54 & 16,67 \\
\hline 7 & 8,55 & 7,42 & 15,23 \\
\hline 8 & 8,18 & 7,10 & 15,21 \\
\hline 9 & 8,15 & 7,07 & 15,28 \\
\hline \multicolumn{4}{|r}{ Kadar air rata-rata } \\
\hline
\end{tabular}


Tabel 5. Kadar air variasi III

\begin{tabular}{|c|c|c|c|}
\hline Benda uji & $\begin{array}{c}\text { Berat awal } \\
\text { (gr) }\end{array}$ & $\begin{array}{c}\text { Berat kering oven } \\
\text { (gr) }\end{array}$ & Kadar air (\%) \\
\hline 1 & 7,45 & 5,20 & 43,27 \\
\hline 2 & 7,30 & 5,85 & 24,79 \\
\hline 3 & 6,90 & 5,22 & 32,18 \\
\hline 4 & 6,85 & 5,10 & 34,31 \\
\hline 5 & 8,32 & 6,10 & 36,39 \\
\hline 6 & 5,51 & 3,81 & 44,62 \\
\hline 7 & 7,65 & 6,07 & 26,03 \\
\hline 8 & 7,03 & 5,55 & 26,67 \\
\hline 9 & 6,95 & 5,24 & 32,63 \\
\hline \multicolumn{4}{|r}{ Kadar air rata-rata } \\
\hline
\end{tabular}

\subsection{Berat Jenis}

Berat jenis kayu dihitung berdasarkan berat kering oven. Hasil pemeriksaaan berat jenis kayu seperti pada Tabel 4.4 berikut ini.

Dari Tabel 6 didapat berat jenis rata-rata kayu kelapa sebesar 0,74. Berdasarkan PKKI 1961 kayu kelapa ini termasuk kelas kuat II karena berat jenis berada antara 0,6 - 0,9.

Tabel 6. Berat jenis kayu kelapa

\begin{tabular}{|c|c|c|c|c|c|c|}
\hline \multirow{2}{*}{$\begin{array}{c}\text { Benda } \\
\text { uji }\end{array}$} & \multicolumn{3}{|c|}{ Dimensi $(\mathrm{cm})$} & \multirow{2}{\text{Volume}}{$\begin{array}{c}\text { Berat } \\
\left(\mathrm{cm}^{3}\right)\end{array}$} & $\begin{array}{c}\text { Berat jenis } \\
(\mathrm{g})\end{array}$ \\
\hline & $\mathrm{P}$ & $\mathrm{l}$ & $\mathrm{t}$ & $\left.\mathrm{cm}^{3}\right)$ \\
\hline 1 & 1,90 & 2,00 & 2,00 & 7,60 & 7,09 & 0,93 \\
\hline 2 & 2,00 & 2,10 & 2,20 & 9,24 & 6,41 & 0,69 \\
\hline 3 & 1,80 & 2,00 & 2,10 & 7,56 & 8,14 & 1,08 \\
\hline 4 & 1,90 & 2,00 & 2,15 & 8,17 & 4,43 & 0,54 \\
\hline 5 & 2,00 & 2,00 & 2,10 & 8,40 & 4,35 & 0,52 \\
\hline 6 & 2,10 & 2,10 & 2,30 & 10,14 & 6,33 & 0,62 \\
\hline 7 & 1,90 & 2,10 & 2,10 & 8,38 & 4,24 & 0,51 \\
\hline 8 & 1,85 & 2,10 & 2,20 & 8,55 & 6,25 & 0,73 \\
\hline 9 & 2,00 & 2,10 & 2,20 & 9,24 & 9,40 & 1,02 \\
\hline \multicolumn{7}{|l}{ Berat jenis rata-rata } \\
\hline
\end{tabular}

\subsection{Kekuatan Sambungan Teoritis}

Berdasarkan berat jenis rata-rata kayu kelapa sebesar 0,74 maka dipakai $\sigma_{\mathrm{kd}}=185$ $\mathrm{kg} / \mathrm{cm}^{2}$.

$$
\mathrm{S}=2 \cdot 0,42.185=155,4 \mathrm{~kg}
$$

Jadi kekuatan teoritis sambungan dengan 10 paku = 10. 155,4 = 1554 kg. 


\subsection{Kekuatan Sambungan Pengujian}

Hasil pengujian kekuatan sambungan seperti dicantumkan pada Tabel 7, 8 dan 9.

Tabel 7. Kekuatan sambungan kayu dengan kadar air 8,27 \%

\begin{tabular}{|c|c|c|c|}
\hline Jarak paku & Benda uji & $\begin{array}{l}\text { Kekuatan maksimum } \\
\text { sambungan }(\mathrm{kg})\end{array}$ & $\begin{array}{c}\text { Kekuatan maks rata-rata } \\
\text { sambungan }(\mathrm{kg})\end{array}$ \\
\hline \multirow{3}{*}{ 8D } & 1 & 4344 & \multirow{3}{*}{4988} \\
\hline & 2 & 4831 & \\
\hline & 3 & 5788 & \\
\hline \multirow{3}{*}{ 10D } & 1 & 5199 & \multirow{3}{*}{5183} \\
\hline & 2 & 5914 & \\
\hline & 3 & 4435 & \\
\hline \multirow{3}{*}{ 12D } & 1 & 6466 & \multirow{3}{*}{5797} \\
\hline & 2 & 5971 & \\
\hline & 3 & 4953 & \\
\hline
\end{tabular}

Tabel 8. Kekuatan sambungan kayu dengan kadar air 16,28 \%

\begin{tabular}{|c|c|c|c|}
\hline Jarak paku & Benda uji & $\begin{array}{c}\text { Kekuatan maksimum } \\
\text { sambungan }(\mathrm{kg})\end{array}$ & $\begin{array}{c}\text { Kekuatan maks rata-rata } \\
\text { sambungan }(\mathrm{kg})\end{array}$ \\
\hline \multirow{3}{*}{ 8D } & 1 & 4983 & \multirow{2}{*}{4} \\
\cline { 2 - 3 } & 2 & 4040 & \multirow{2}{*}{4373} \\
\cline { 2 - 3 } & 3 & 4098 & \multirow{2}{*}{4} \\
\hline \multirow{3}{*}{ 10D } & 1 & 4424 & \multirow{2}{*}{449} \\
\cline { 2 - 3 } & 2 & 4582 & \multirow{2}{*}{5} \\
\cline { 2 - 3 } & 3 & 4343 & \multirow{2}{*}{5803} \\
\hline \multirow{3}{*}{ 12D } & 1 & 6134 & \multicolumn{2}{|c|}{} \\
\cline { 2 - 3 } & 2 & 5220 & \multicolumn{2}{|c|}{} \\
\cline { 2 - 3 } & 3 & 6056 & \multicolumn{2}{|c|}{} \\
\hline
\end{tabular}

Tabel 9. Kekuatan sambungan kayu dengan kadar air 33,44 \%

\begin{tabular}{|c|c|c|c|}
\hline Jarak paku & Benda uji & $\begin{array}{l}\text { Kekuatan maksimum } \\
\text { sambungan }(\mathrm{kg})\end{array}$ & $\begin{array}{c}\text { Kekuatan maks rata-rata } \\
\text { sambungan (kg) }\end{array}$ \\
\hline \multirow{3}{*}{$8 \mathrm{D}$} & 1 & 4099 & \multirow{3}{*}{4193} \\
\hline & 2 & 3916 & \\
\hline & 3 & 4564 & \\
\hline \multirow{3}{*}{ 10D } & 1 & 4875 & \multirow{3}{*}{4400} \\
\hline & 2 & 4236 & \\
\hline & 3 & 4087 & \\
\hline \multirow{3}{*}{$12 \mathrm{D}$} & 1 & 4722 & \multirow{3}{*}{4891} \\
\hline & 2 & 5149 & \\
\hline & 3 & 4802 & \\
\hline
\end{tabular}

Hubungan antara jarak paku dan kekuatan sambungan pada berbagai variasi kadar air dapat dilihat pada Tabel 10 dan Gambar 2. 
Tabel 10. Hubungan kekuatan sambungan dengan jarak paku

\begin{tabular}{|c|c|c|c|}
\hline $\begin{array}{c}\text { Kadar air } \\
(\%)\end{array}$ & Jarak paku & $\begin{array}{c}\text { Kekuatan maksimum } \\
\text { sambungan (kg) }\end{array}$ & $\begin{array}{c}\text { Perbandingan kekuatan sambungan } \\
\text { terhadap jarak paku minimum 10D } \\
(\%)\end{array}$ \\
\hline \multirow{3}{*}{8,27} & 8D & 4988 & 96 \\
\cline { 2 - 4 } & 10D & 5183 & 100 \\
\cline { 2 - 4 } & $12 \mathrm{D}$ & 5797 & 112 \\
\hline \multirow{3}{*}{16,28} & 8D & 4373 & 98 \\
\cline { 2 - 4 } & $10 \mathrm{D}$ & 4449 & 100 \\
\cline { 2 - 4 } & $12 \mathrm{D}$ & 5803 & 130 \\
\hline \multirow{3}{*}{33,44} & 8D & 4193 & 95 \\
\cline { 2 - 4 } & $10 \mathrm{D}$ & 4400 & 100 \\
\cline { 2 - 4 } & 12D & 4891 & 111 \\
\hline
\end{tabular}

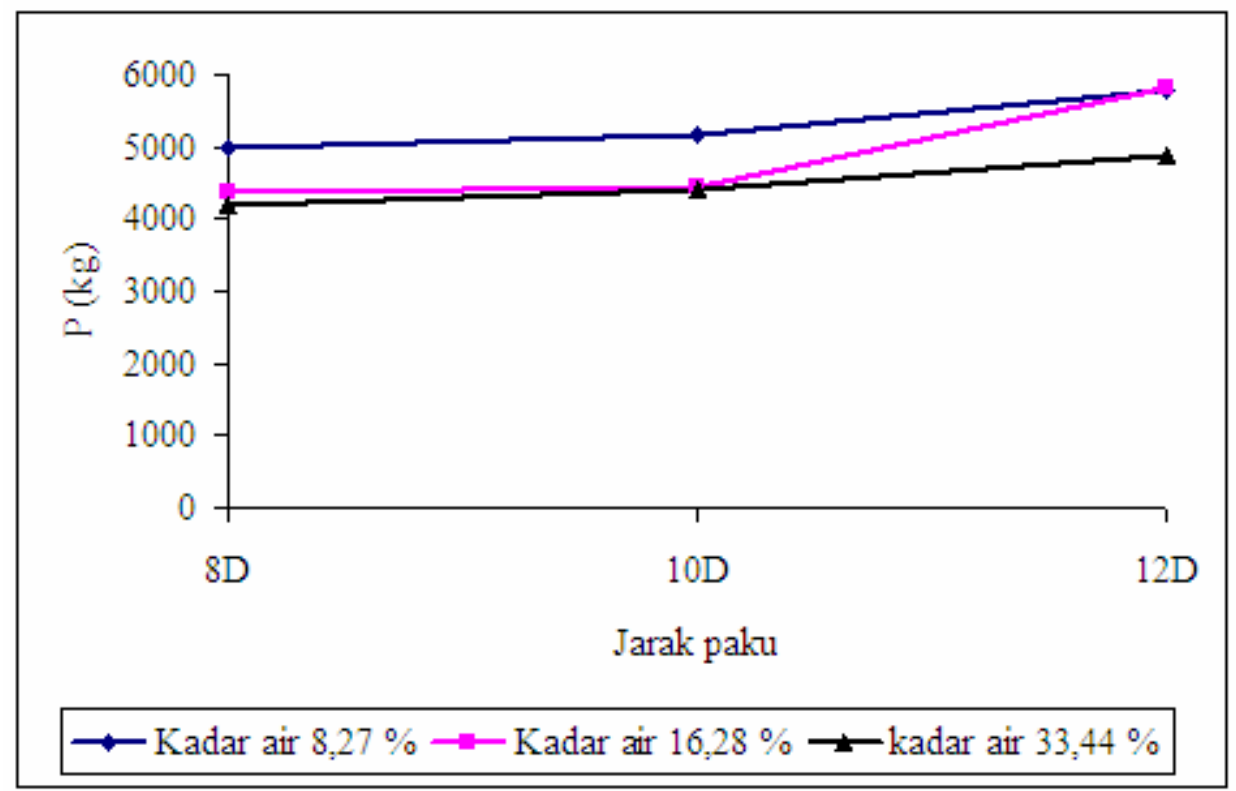

Gambar 2. Hubungan antara jarak paku dengan kekuatan sambungan

Berdasarkan PKKI 1961 jarak minimum antar paku dalam 1 baris sebesar 10D. Dari Tabel 10 dan Gambar 2 dapat dilihat bahwa kekuatan sambungan pada setiap variasi kadar air dipengaruhi oleh jarak antar paku. Jarak paku yang kurang dari jarak minimum mengakibatkan penurunan kekuatan sambungan dan jarak paku yang lebih besar dari jarak minimum meningkatkan kekuatan sambungan. Dari hasil ini dapat ditarik kesimpulan bahwa pendetailan mempengaruhi kekuatan sambungan.

Hubungan antara variasi kadar air dan kekuatan sambungan pada berbagai jarak paku dapat dilihat pada Tabel 11 dan Gambar 3. 
Tabel 11. Hubungan kekuatan sambungan dengan kadar air

\begin{tabular}{|c|c|c|c|}
\hline Jarak paku & $\begin{array}{c}\text { Kadar air } \\
(\%)\end{array}$ & $\begin{array}{c}\text { Kekuatan maksimum } \\
\text { sambungan (kg) }\end{array}$ & $\begin{array}{c}\text { Perbandingan kekuatan sambungan } \\
\text { terhadap kadar air 16,28 \% }\end{array}$ \\
\hline \multirow{3}{*}{$8 \mathrm{D}$} & 8,27 & 4988 & 114 \\
\cline { 2 - 4 } & 16,28 & 4373 & 100 \\
\cline { 2 - 4 } & 33,44 & 4193 & 96 \\
\hline \multirow{3}{*}{$10 \mathrm{D}$} & 8,27 & 5183 & 116 \\
\cline { 2 - 4 } & 16,28 & 4449 & 100 \\
\cline { 2 - 4 } & 33,44 & 4400 & 99 \\
\hline \multirow{3}{*}{ 12D } & 8,27 & 5797 & 100 \\
\cline { 2 - 4 } & 16,28 & 5803 & 100 \\
\cline { 2 - 4 } & 33,44 & 4891 & 84 \\
\hline
\end{tabular}

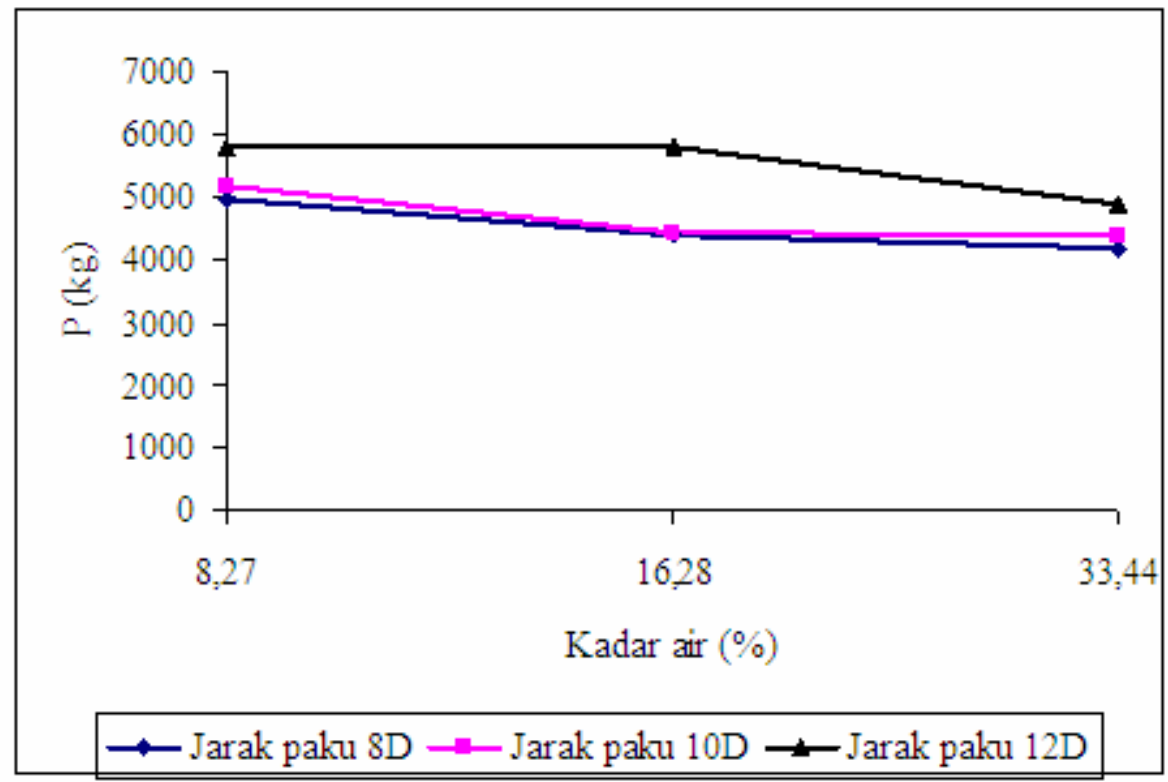

Gambar 3. Hubungan antara kadar air dengan kekuatan sambungan

Berdasarkan PKKI 1961 kadar air kering udara berkisar antara 12 -18 \% atau ratarata $15 \%$, jadi kayu kelapa dengan kadar air 16,28 \% dapat dianggap sudah mencapai kering udara. Dari Tabel 11 dan Gambar 3 dapat dilihat bahwa kekuatan sambungan pada setiap jarak paku dipengaruhi oleh kadar air kayu. Kadar air kayu yang kurang dari kadar air kering udara atau hampir sama dengan kadar air kayu di dalam ruang mengakibatkan peningkatan kekuatan sambungan dan kadar air yang melebihi kadar air kering udara menurunkan kekuatan sambungan. Hal ini diakibatkan oleh kekuatan sel kayu dipengaruhi oleh kadar air.

Perbandingan hasil pengujian sambungan kayu kelapa dengan hasil perhitungan teoritis seperti ditunjukkan pada Tabel 12. 
Tabel 12. Perbandingan hasil pengujian sambungan dengan hasil peritungan teoritis

\begin{tabular}{|c|c|c|c|c|}
\hline Jarak paku & $\begin{array}{c}\text { Kadar air } \\
(\%)\end{array}$ & $\begin{array}{c}\text { Kekuatan maksimum } \\
\text { sambungan }(\mathrm{kg})\end{array}$ & $\begin{array}{c}\text { Hasil perhitungan } \\
\text { teoritis }(\mathrm{kg})\end{array}$ & Perbandingan \\
\hline \multirow{3}{*}{$8 \mathrm{D}$} & 8,27 & 4988 & 1554 & 3.21 \\
\cline { 2 - 5 } & 16,28 & 4373 & 1554 & 2.81 \\
\cline { 2 - 5 } & 33,44 & 4193 & 1554 & 2.70 \\
\hline \multirow{3}{*}{ 10D } & 8,27 & 5183 & 1554 & 3.34 \\
\cline { 2 - 5 } & 16,28 & 4449 & 1554 & 2.86 \\
\cline { 2 - 5 } & 33,44 & 4400 & 1554 & 2.83 \\
\hline \multirow{3}{*}{ 12D } & 8,27 & 5797 & 1554 & 3.73 \\
\cline { 2 - 5 } & 16,28 & 5803 & 1554 & 3.73 \\
\cline { 2 - 5 } & 33,44 & 4891 & 1554 & 3.15 \\
\hline
\end{tabular}

Dari Tabel 12 dapat dilihat bahwa pada jarak paku yang sama, perbandingan kekuatan maksimum hasil pengujian dan hasil perhitungan teoritis (faktor aman) semakin kecil dengan meningkatnya kadar air.

Pada kadar air yang sama jarak paku mempengaruhi besarnya faktor aman, semakin besar jarak paku meningkatkan faktor aman. Jadi pada perhitungan kekuatan sambungan paku pada kayu kelapa perlu diperhitungkan faktor reduksi akibat pendetailan alat sambung dan pengaruh kadar air.

Besarnya faktor aman pada sambungan kayu kelapa yang menggunakan alat sambung paku pada kondisi kering udara (kadar air 16,28 \%) dan dengan jarak antar paku sesuai dengan peraturan 10D sebesar 2,86.

\section{KESIMPULAN DAN SARAN}

\subsection{Kesimpulan}

1. Kaya kelapa termasuk kayu kelas kuat II dengan berat jenis rata-rata 0,74.

2. Jarak antar paku yang kurang dari jarak minimum berdasarkan peraturan mengurangi kekuatan sambungan dan jarak yang lebih besar dari jarak minimum meningkatkan kekuatan sambungan.

3. Pada kadar air dibawah kondisi kering udara kekuatan sambungan paku mengalami peningkatan dan pada kadar air diatas kondisi kering udara mengalami penurunan.

4. Peningkatan kadar air akan memperkecil faktor aman dan penambahan jarak antar paku meningkatkan faktor aman.

5. Besarnya faktor aman sambungan kayu kelapa pada kondisi kering udara dan dengan jarak paku sesuai peraturan sebesar 2,86. 


\subsection{Saran}

1. Perlu dilakukan penelitian sambungan kayu kelapa menggunakan alat sambung paku dengan kekuatan sambungan sama atau lebih besar dengan kekuatan kayu yang disambung sehingga pengaruh kadar air menjadi lebih jelas.

2. Kadar air benda uji sebaiknya dibuat lebih bervariasi lagi misalnya kering, kering udara, kadar air seimbang dan basah sehingga perbedaan kekuatan sambungan akibat perbedaan kadar air ini lebih kelihatan.

3. Jarak antar paku sebaiknya dibuat lebih bervariasi lagi, khususnya jarak antar paku yang lebih besar dari jarak minimum sehingga dapat diketahui sampai jarak berapa paku masih dapat bekerja sama dan mulai pada jarak berapa paku bekerja sendiri-sendiri.

\section{DAFTAR PUSTAKA}

1. Anonim (1961), Peraturan Konstruksi Kayu Indonesia 1961, Direktorat Penyelidikan Masalah Bangunan, Bandung.

2. Dumanauw J.F. (1984), Mengenal Kayu, Pendidikan Industri Kayu (PIKA), Semarang.

3. Haygreen, J.G., Bowyer, J.L. (1996), Hasil Hutan dan Ilmu Ukur Kayu, Universitas Gadjah Mada, Yogyakarta.

4. Isyuanto, S. (2002), Kajian Sifat Mekanik Kayu Kelapa Sebagai Kayu Alternatif di Bidang Konstruksi, Skripsi, FT UJB, Yogyakarta.

5. Kasmujo (2001), Identifikasi Kayu dan Sifat-sifat Kayu, Fakultas Kehutanan, Universitas Gadjah Mada, Yogyakarta.

6. Sektianto, W. (2001), Tinjauan Sifat Mekanika Kayu Pohon Kelapa Terhadap Rendaman Gamping Dan Daun Jati, Skripsi, FT UJB, Yogyakarta.

7. Setyamidjaja (1995), Jenis Kayu Sebagai Bahan Baku Industri Kayu, Fakultas Kehutanan Universitas Gadjah Mada, Yogyakarta.

8. Soehendrajati, R.J.B. (1990), Kayu untuk Struktur Jilid 1, Bahan Kuliah Jurusan Teknik Sipil, Fakultas Teknik, Universitas Gajah Mada, Yogyakarta.

[1] Arusmalem Ginting, S.T., M.T., Dosen Tetap Jurusan Teknik Sipil, Universitas Janabadra Yogyakarta. E-mail : agintm@yahoo.com 